\title{
Fire resistance of concrete walls with light aggregate
}

\author{
Hertz, Kristian Dahl
}

Published in:

Journal of Structural Fire Engineering

Link to article, DOI:

10.1108/JSFE-11-2017-0043

Publication date:

2018

Document Version

Peer reviewed version

Link back to DTU Orbit

Citation (APA):

Hertz, K. D. (2018). Fire resistance of concrete walls with light aggregate. Journal of Structural Fire Engineering, 9(4), 319-341. https://doi.org/10.1108/JSFE-11-2017-0043

\section{General rights}

Copyright and moral rights for the publications made accessible in the public portal are retained by the authors and/or other copyright owners and it is a condition of accessing publications that users recognise and abide by the legal requirements associated with these rights.

- Users may download and print one copy of any publication from the public portal for the purpose of private study or research.

- You may not further distribute the material or use it for any profit-making activity or commercial gain

- You may freely distribute the URL identifying the publication in the public portal

If you believe that this document breaches copyright please contact us providing details, and we will remove access to the work immediately and investigate your claim 


\title{
Fire resistance of concrete walls with light aggregate
}

\author{
Kristian Hertz \\ Department of Civil Engineering, Technical University of Denmark, \\ DK-2800 Kgs Lyngby, Denmark
}

\begin{abstract}
Purpose - The paper presents design methods for fire exposed concrete columns and walls. In addition, it presents analyses and tests showing that the methods are applicable for designing columns and walls of lightweight concrete based on expanded clay aggregate as well as normal weight concrete and that the methods fit smoothly with cold design, when the fire exposure varies towards no fire.

Design/methodology/approach - During the nineties, some of these design methods were included in the Eurocode as "the zone method'. They are still a part of the code. The rest of the methods, which were not included, served in practice, teaching, and research. The present paper derives calculation methods proving their connection with common design for load cases without fire exposure. Furthermore, the paper presents full-scale tests proving the validation of the design methods for structural members of light aggregate concrete in addition to the full-scale tests of heavy concrete members.

Findings - The design methods give correct estimates of the load-bearing capacity of eccentric loaded concrete columns. An extended version of the methods estimates load-bearing capacity for walls with fire exposure on one side with sufficient accuracy for the purpose of design.

Originality value - The author developed the main parts of the design methods in the eighties and nineties and others have from time to time referred to some parts of them mainly the minor parts published in the Eurocodes. However, due to work overload the author has not published the derivation and verification of them before. This paper provides in particular a verification against full-scale tests of light-aggregate concrete walls not published before.
\end{abstract}

Keywords: Fire test, walls, design methods, light aggregate concrete, load-bearing capacity

\section{Acknowledgements}

I would like to record my sincere thanks to the society of Danish producers of expanded clay aggregate concrete elements called Dansk Beton Industriforening (DBI), Element fraction (BIH) and Block fraction (BIB) and to Scan Brann Blokk for financing a number of full-scale tests. These tests can not only serve as a documentation for the calculation of expanded clay aggregate elements but also contribute to the documentation for calculation of fire exposed concrete constructions in general. 

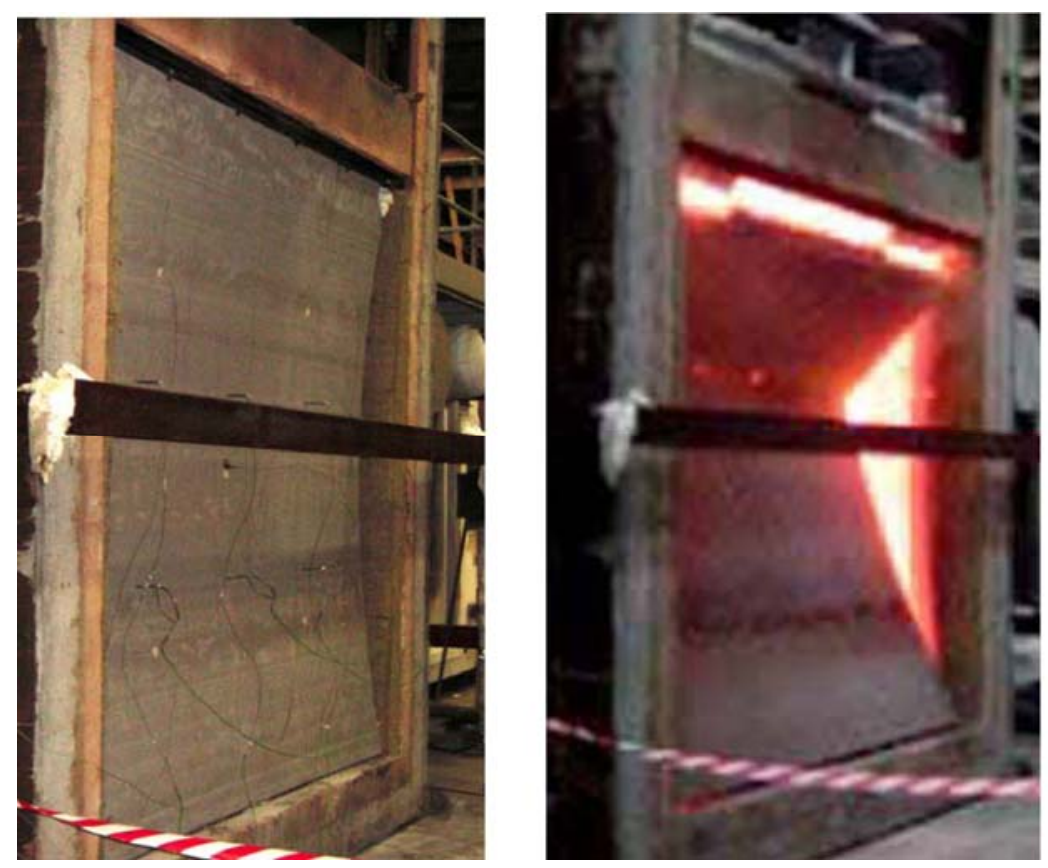

Figure 1. Eccentric loaded $100 \mathrm{~mm}$ wall of concrete $1800 \mathrm{~kg} / \mathrm{m}^{3}$ in fire test at $80 \mathrm{~min}$ and at failure at $85 \mathrm{~min}$.

\section{Introduction}

Light weight concrete based on expanded clay aggregate differ from traditional normal weight concrete mainly by weight and thermal conductivity. However, substantial mechanical properties such as strength and stiffness, varies in temperature according to the same principles as known from other concrete qualities although other parameters apply. It is therefore logical to presume that the basis for calculation of fire resistance of these structures accord with the basis for calculating fire resistance of structures of ordinary heavy concrete.

The author have previously developed such design methods as for example expressed in the Danish Standard DS 411 from 1999 or the simplified calculation method in chapter 4.3 of the CEN pre-code printed as ENV 1992-1-2 from 1995 and the code EN 1992-1-2 from 2004.

In addition, he presented a basis for fire safety calculations of columns of ordinary heavy and light aggregate concrete in the little known DTU reports: "Calculation method for fire safety design of constructions of expanded clay aggregate concrete" (in Danish) from 1997 and "Comments on simplified calculation method for fire exposed concrete columns" from 1998.

Recently, Achenbach and Morgenthal in 2016 proved good agreement for application of the author's zone method as presented in the early report "Analyses of prestressed concrete structures exposed to fire" from 1985 making minor empirical corrections of the reinforcement properties. However, they do not derive the expressions proving a general validity of the method and improving it for application for any column and wall at any time of any fire exposure. Such derivation is therefore presented in this paper.

During the project, we made a number of full-scale tests in order to provide a reasonable documentation for the application of the calculation methods especially for light-aggregate concrete walls. The present paper comprises results of the tests with reference to the report "Fire safety design of expanded clay aggregate concrete structures - Calculation of fire resistance time" (in Danish) from 2001. In addition, we include results from a Norwegian full scale test on a wall of Scan Brann Blokk. 


\section{Material properties}

In this project, we apply light aggregate concrete of density $1800,1200,900$, and $600 \mathrm{~kg} / \mathrm{m}^{3}$ with thermal conductivities as sown in Table 1 . The thermal capacity is $1 \mathrm{~kJ} / \mathrm{kg}^{\circ} \mathrm{C}$ for all qualities.

\begin{tabular}{|l|l|l|l|l|l|}
\hline 2300 & 1800 & 1200 & 900 & 600 & $\mathrm{~kg} / \mathrm{m}^{3}$ \\
\hline 1.0 & 0.9 & 0.45 & 0.40 & 0.3 & $\mathrm{~W} / \mathrm{m}^{\circ} \mathrm{C}$ \\
\hline
\end{tabular}

Table 1 Conductivity values applied for varying densities of concrete.

We assess values for compressive strength, tensile strength, and E-modulus of the expanded clay aggregate concretes used for the tests as average values in order to make the calculations comparable to the test results. For simplicity, we assess fixed values of the thermal conductivity used in simple temperature calculations as the values from steady state tests at $500^{\circ} \mathrm{C}$.

Calculations of strength reduction of concrete and steel uses the general expression

$$
\xi(\mathrm{T})=\mathrm{k}+\frac{1-\mathrm{k}}{1+\frac{\mathrm{T}}{\mathrm{T}_{1}}+\left(\frac{\mathrm{T}}{\mathrm{T}_{2}}\right)^{2}+\left(\frac{\mathrm{T}}{\mathrm{T}_{8}}\right)^{8}+\left(\frac{\mathrm{T}}{\mathrm{T}_{64}}\right)^{64}}
$$

which is presented in Hertz (2005) for concrete and (2004) and (2006) for reinforcement and steel. The Greek letter $\xi$ means a reduction at a temperature $\mathrm{T}^{\circ} \mathrm{C}$.

$\mathrm{T}_{1}$ to $\mathrm{T}_{64}$ are parameters with the unit ${ }^{\circ} \mathrm{C}$ describing the curve.

$\mathrm{k}$ is a minimum strength fraction, which is left for steel after cooling. $\mathrm{k}$ is always 0 for concrete.

The parameters have the values shown in Table 2 for different concrete qualities:

\begin{tabular}{|l|c|c|c|c|c|}
\hline & $\mathrm{k}$ & $\mathrm{T}_{1}$ & $\mathrm{~T}_{2}$ & $\mathrm{~T}_{8}$ & $\mathrm{~T}_{64}$ \\
\hline Siliceous concrete HOT & 0.00 & 15000 & 800 & 570 & 100000 \\
\hline Siliceous concrete COLD & 0.00 & 3500 & 600 & 480 & 680 \\
\hline Main group concrete HOT & 0.00 & 100000 & 1080 & 690 & 1000 \\
\hline Main group concrete COLD & 0.00 & 10000 & 780 & 490 & 100000 \\
\hline Light aggregate concrete HOT & 0.00 & 100000 & 1100 & 800 & 940 \\
\hline Light aggregate concrete COLD & 0.00 & 4000 & 650 & 830 & 930 \\
\hline
\end{tabular}

Table 2 Parameters for design reduction of compressive strength of concrete in a HOT condition during a fire and in a COLD condition after a fire.

The parameters have the values shown in Table 3 for different reinforcement steel qualities.

Please observe, that the values presented as "effective yield strength" in Eurocodes like EN 1992-1-2 (2004) do not represent the yield strength often given as a $0.2 \%$ strenght. Instead they represent an ultimate strength at an elongation of $2.0 \%$. Usually you cannot apply these values for design, since a structure will deflect so much before the strain is $2.0 \%$ that it usually must be considered to fail.

The steel code committee first called these values "yield strength" until the author pointed this out in a letter to the central code committee Hertz (1993) published in Hertz (2004).

This resulted in change of the name instead of change of the properties. 


\begin{tabular}{|l|r|r|r|r|r|}
\hline & \multicolumn{1}{|c|}{$\mathrm{k}$} & \multicolumn{1}{c|}{$\mathrm{T}_{1}$} & \multicolumn{1}{c|}{$\mathrm{T}_{2}$} & \multicolumn{1}{c|}{$\mathrm{T}_{8}$} & \multicolumn{1}{c|}{$\mathrm{T}_{64}$} \\
\hline Hot rolled bars 0.2 \% stress HOT & 0.000 & 6000 & 620 & 565 & 1100 \\
\hline Hot rolled bars 2.0\% stress HOT & 0.000 & 100000 & 100000 & 593 & 100000 \\
\hline Hot rolled bars 0.2 \% residual stress COLD & 1.000 & 100000 & 100000 & 100000 & 100000 \\
\hline Hot rolled bars 2.0\% residual stress COLD & 1.000 & 100000 & 100000 & 100000 & 100000 \\
\hline Cold worked bars 0.2 \% stress HOT & 0.000 & 100000 & 900 & 555 & 100000 \\
\hline Cold worked bars 2.0\% stress HOT & 0.000 & 100000 & 5000 & 560 & 100000 \\
\hline Cold worked bars 0.2\% residual stress COLD & 0.580 & 100000 & 5000 & 590 & 730 \\
\hline Cold worked bars 2.0\% residual stress COLD & 0.520 & 100000 & 1500 & 580 & 650 \\
\hline C-w prestressing steel 0.2\% stress HOT & 0.000 & 2000 & 360 & 430 & 100000 \\
\hline C-w prestressing steel 2.0\% stress HOT & 0.000 & 100000 & 490 & 450 & 100000 \\
\hline C-w prestressing steel 0.2\% residual stress COLD & 0.200 & 100000 & 750 & 550 & 650 \\
\hline C-w prestressing steel 2.0\% residual stress COLD & 0.200 & 100000 & 950 & 550 & 650 \\
\hline Quenched and Tempered 1500 MPa 0.2\% stress HOT & 0.000 & 1100 & 100000 & 430 & 100000 \\
\hline Quenched and Tempered 1500 MPa 2.0\% stress HOT & 0.000 & 3000 & 1400 & 450 & 100000 \\
\hline Quenched and Tempered 1500 MPa 0.2\% stress COLD & 0.213 & 100000 & 10000 & 590 & 660 \\
\hline Quenched and Tempered 1500 MPa 2.0\% stress COLD & 0.213 & 100000 & 10000 & 590 & 660 \\
\hline Quenched and Self-tempered 550 MPa 0.2\% stress HOT & 0.000 & 6000 & 1150 & 540 & 700 \\
\hline Quenched and Self-tempered 550 MPa 2.0\% stress HOT & 0.000 & 100000 & 100000 & 590 & 700 \\
\hline Quenched and Self-tempered 550 MPa 0.2\% stress COLD & 0.418 & 100000 & 100000 & 700 & 900 \\
\hline Quenched and Self-tempered 550 MPa 2.0\% stress COLD & 0.437 & 100000 & 100000 & 700 & 900 \\
\hline
\end{tabular}

Table 3. Parameters for design reduction of $0.2 \%$ and $2.0 \%$ stresses of different reinforcement steels during a fire (HOT) and after a fire exposure (COLD).

By studying the relations between temperature dependent strength and E-modulus of more than 170 test series in Hertz (1980) including the comprehensive test series of 230 specimens of Danish sea gravel based concrete, the author found that they all fit satisfactory to the following idealised expression:

$$
\mathrm{E}_{\mathrm{c}}=\xi_{\mathrm{c}}^{2} \mathrm{E}_{\mathrm{c} 20}, \quad \mathrm{f}_{\mathrm{cc}}=\xi_{\mathrm{c}} \mathrm{f}_{\mathrm{cc} 20}
$$

Where $\mathrm{E}_{\mathrm{c}}$ is the E-modulus of the concrete at the temperature level in question, $\mathrm{E}_{\mathrm{c} 20}$ is the E-modulus of the concrete at $20^{\circ} \mathrm{C}, \xi_{\mathrm{c}}$ is the reduction of the compressive strength $\mathrm{f}_{\mathrm{cc} 20}$ of the concrete at $20^{\circ} \mathrm{C}$.

Different test series investigated by the author show that this relation appears to be valid for a large variety of concretes in a HOT condition during fire as well as in a COLD after the cooling phase. For reinforcing steel the similar model is different. Here the E-modulus $\mathrm{E}_{\mathrm{s}}$ is reduced by the reduction $\xi_{\mathrm{s}}$ in strength $\mathrm{f}_{\mathrm{s}}$

$$
\mathrm{E}_{\mathrm{s}}=\xi_{\mathrm{s}} \mathrm{E}_{\mathrm{s} 20}, \quad \mathrm{f}_{\mathrm{s}}=\xi_{\mathrm{s}} \mathrm{f}_{\mathrm{s} 20}
$$

During the author's investigations on Danish sea gravel concrete he noticed a considerable increase of the ultimate strain $\varepsilon_{c u}$ in temperature. You can make the same observation from stress-strain curves for various concretes with - or without application of load during heating and tested in a HOT or in a COLD condition, as they are reported in the literature. See for example Schneider (1977), Harmathy and Berndt (1966), Harada et al. (1972), and Fischer (1970). 


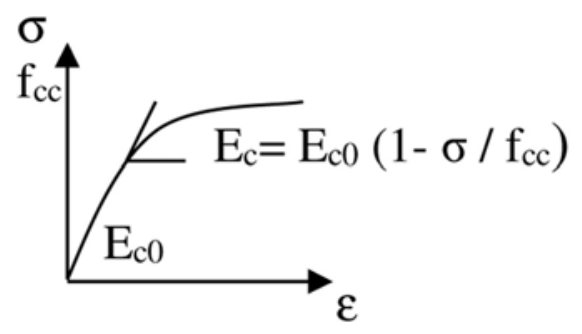

Figure 2. The Ritter assumption

From the stress-strain curves for heated concrete it can also be seen that the increase in strain follows the decrease in stress according to a simple model where the product of stress and strain remains a constant for each point of the stress-strain curve while the material is weakened due to the heat. Thus, the ultimate strain will be increased by the reciprocal reduction of the compressive strength

$\varepsilon_{\mathrm{cu}}=\varepsilon_{\mathrm{cu} 20} / \xi_{\mathrm{c}}$, which is in accordance with the test results.

Here we usually assess $\varepsilon_{\mathrm{cu} 20}$ to be $0.35 \%$.

We mainly apply a stress-strain curve of a concrete in order to estimate deflection of a beam, column, or wall, and we apply deflection of walls and columns for calculating a critical load, where the specimen becomes instable. This means that the stress-strain curve applied preferably should fit in simple instability calculations. The author has found that all this can be obtained by application of stressstrain curves that fulfil the assumption made by Ritter (Figure 2) that the E-modulus $\mathrm{E}_{\mathrm{c}}$ of a concrete at a certain stress $\sigma$ is $E_{c}=E_{c 0}\left(1-\sigma / f_{c c}\right)$.

Ritter's assumption constitutes a differential equation

$$
\frac{d \sigma}{d \varepsilon}=E_{c 0}-\frac{E_{c 0}}{f_{c c}} \sigma \Rightarrow \sigma(\varepsilon)=f_{c c}\left(1-e^{\frac{-E_{c} 0}{f_{c c}} \varepsilon}\right)
$$

That gives an expression for the stress-strain curve of any concrete at any temperature level T as:

$$
\sigma(\varepsilon, T)=\xi(T) f_{c c 20}\left(1-e^{\frac{-E_{c 020} \xi(T)}{f_{c c 20}} \varepsilon}\right)
$$

An example of stress-strain curves for varying temperatures is shown on Figure 3.

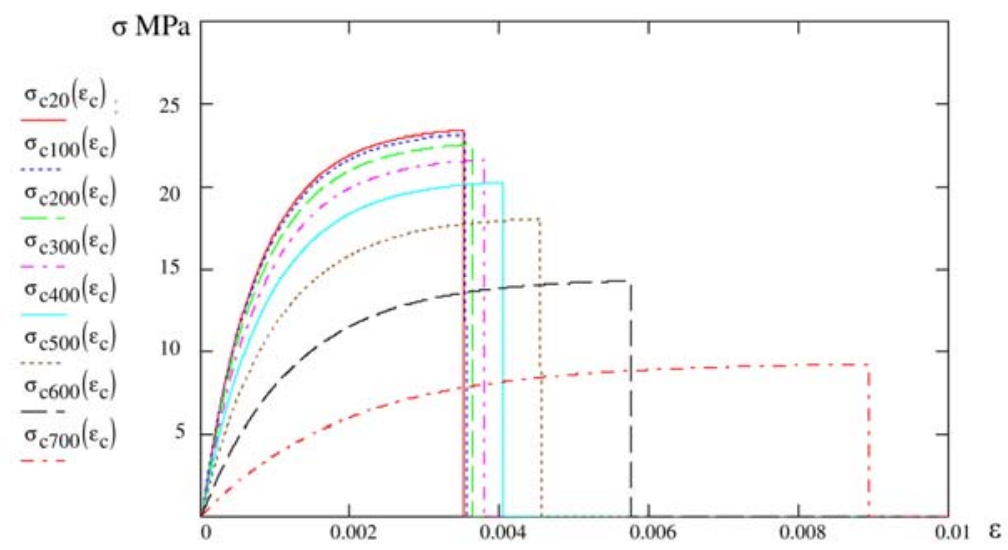

Figure 3. Stress-strain curves for a 23.6 MPa main group concrete in a HOT condition. 


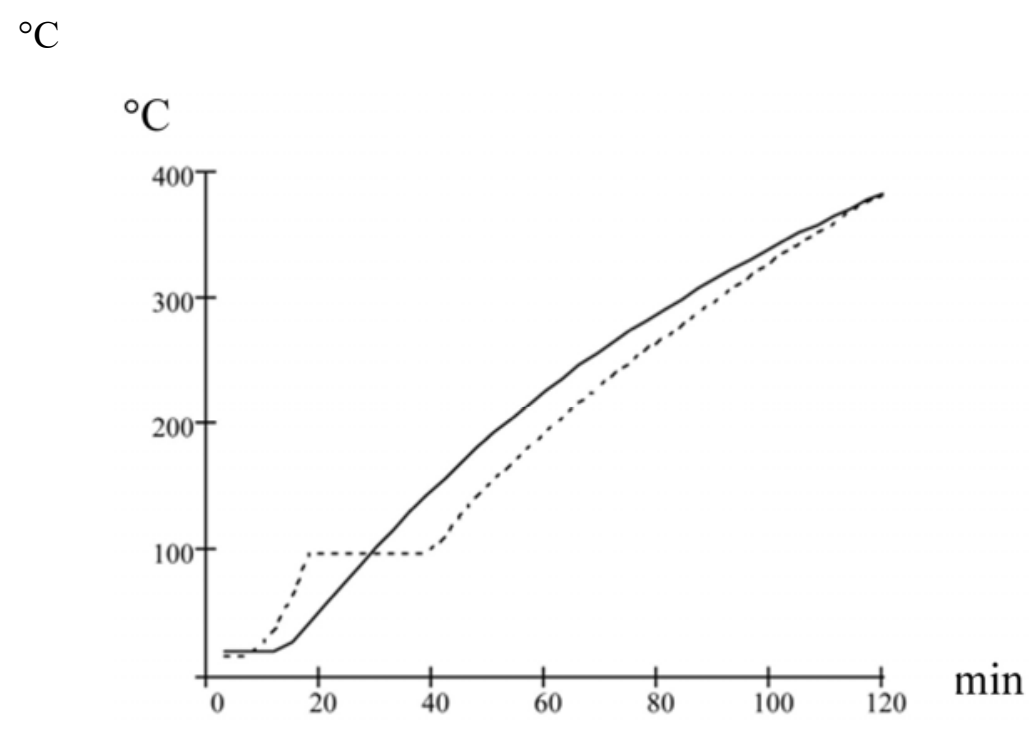

Figure 4. Example of temperature-time curve in depth $\mathrm{x}=50 \mathrm{~mm}$ of an ISO 834 standard fire exposed wall of concrete $1800 \mathrm{~kg} / \mathrm{m}^{3}$. Calculated ....Measured

\section{Temperature calculations}

For temperature calculations you may use a simplified method developed by the author and adopted in the Danish concrete code DS 411 (1999) representing an exact solution to the Fourier equation for heat conduction with a sinus variation of the surface temperature.

$$
\mathrm{T}_{0}(\mathrm{x}, \mathrm{t})=312 \log (8 \mathrm{t}+1) \exp (-1.9 \mathrm{k}(\mathrm{t}) \mathrm{x}) \sin \left(\frac{\pi}{2}-\mathrm{k}(\mathrm{t}) \mathrm{x}\right) \quad \text { where } \mathrm{k}(\mathrm{t})=\sqrt{\frac{\pi \rho \mathrm{c}_{\mathrm{p}}}{750 \lambda \mathrm{t}}}
$$

Here $\mathrm{t}$ is time in minutes, $\rho$ density in $\mathrm{kg} / \mathrm{m}^{3}, \mathrm{c}_{\mathrm{p}}$ specific enthalpy in $\mathrm{J} / \mathrm{kg}^{\circ} \mathrm{C}$ and $\lambda$ conductivity in $\mathrm{W} / \mathrm{m}^{\circ} \mathrm{C}$ of the concrete. The only approximation of this solution is assessment of the surface temperature variation for a standard fire exposure as the first quarter of a sinus cycle.

The simplified solution allows a quicker calculation of the varying temperature profiles and stressstrain profiles through the structure than if we applied for example a finite difference method like the one used in the free ConFire program (Hertz 2012) that can be downloaded from the home-page of the Department of Civil Engineering, Technical University of Denmark.

In addition, we obtain the benefit of an exact solution.

In the first phase of the full scale wall tests we tested walls constructed of Light aggregate concrete of quality 600,1200 and $1800 \mathrm{~kg} / \mathrm{m}^{3}$ (Conductivities are found in Table 1) and thickness $100 \mathrm{~mm}$ (Andersen (2000), Hertz and Hansen (2001), and Hertz (2002)).

We recorded the temperature profiles and compared them to calculated temperature distributions giving a reasonable agreement between calculation and test.

Figure 4 shows an example. The measured temperature is constant for 20 minutes due to evaporation at $100^{\circ} \mathrm{C}$, where the calculation includes the effect in a less direct manner. 


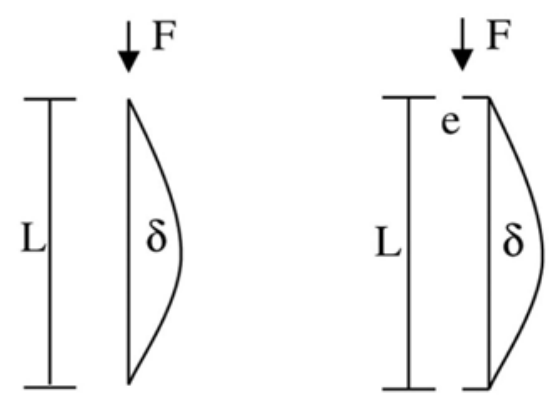

Figure 5. Central and eccentric loaded column.

\section{Column calculations}

The well-known Euler formula assumes a sinus deflection of a centrally loaded column.

$$
\begin{aligned}
& \mathrm{y}=\delta \sin \left(\frac{\pi}{\mathrm{L}} \mathrm{x}\right) \Rightarrow \frac{\mathrm{dy}}{\mathrm{dx}}=\frac{\pi}{\mathrm{L}} \delta \cos \left(\frac{\pi}{\mathrm{L}} \mathrm{x}\right) \Rightarrow \frac{\mathrm{d}^{2} \mathrm{y}}{\mathrm{dx}^{2}}=-\frac{\pi^{2}}{\mathrm{~L}^{2}} \delta \sin \left(\frac{\pi}{\mathrm{L}} \mathrm{x}\right) \\
& \frac{\mathrm{d}^{2} \mathrm{y}}{\mathrm{dx}^{2}}=\kappa \text { and } \delta \mathrm{F}=-\kappa \mathrm{E}_{0} \mathrm{I} \Rightarrow \delta \mathrm{F}=\frac{\pi^{2}}{\mathrm{~L}^{2}} \delta \mathrm{E}_{0} \mathrm{I} \Rightarrow \mathrm{F}_{\mathrm{E}}=\frac{\pi^{2} \mathrm{E}_{0} \mathrm{I}}{\mathrm{L}^{2}}
\end{aligned}
$$

Here $\mathrm{y}$ is the deflection in the length $\mathrm{x}$, which is $\delta$ at the midpoint, where the curvature is $\kappa$ The column length is $\mathrm{L}, \mathrm{F}$ is the force, and $\mathrm{I}$ is the moment of inertia of the cross section.

Inserting the Ritter assumption and thereby the stress-strain curves found from it above we get

$$
\mathrm{F}_{\mathrm{R}}=\frac{\pi^{2} \mathrm{IE}_{0}}{\mathrm{~L}^{2}}\left(1-\frac{\mathrm{F}}{\mathrm{F}_{\mathrm{u}}}\right) \Leftrightarrow \underline{\underline{\frac{1}{\mathrm{~F}_{\mathrm{R}}}=\frac{1}{\mathrm{~F}_{\mathrm{u}}}+\frac{1}{\mathrm{~F}_{\mathrm{E}}}}}
$$

Here $F_{u}$ is the ultimate load for the cross-section $A$ in compression. $F_{R}$ is the ultimate load for the centrally loaded column with the curved stress-strain curve given by the Ritter assumption.

This is a convenient expression for the Rankine formula applied in most textbooks and codes on concrete structures, although it usually appears as expressions, which are hard to recognize.

All reinforcement obtain a curved stress-strain curve when heated. You can therefore find a Rankine load-bearing capacity for a column consisting of reinforcing bars alone presuming that something keeps their mutual distance when deflected. Combining the two expressions you get an extended Rankine formula for a centrally loaded reinforced ( $\mathrm{s}$ for steel) concrete (c for concrete) column.

$$
\underline{\underline{\frac{1}{\mathrm{~F}_{\mathrm{R}}}=\frac{1}{\mathrm{~F}_{\mathrm{su}}+\mathrm{F}_{\mathrm{cu}}}+\frac{1}{\mathrm{~F}_{\mathrm{sE}}+\mathrm{F}_{\mathrm{cE}}}}}
$$

For an eccentric loaded column (Figure 5) a condition of equilibrium is made similar to the one for central load.

$$
\begin{aligned}
& (\mathrm{e}+\delta) \mathrm{F}=\frac{\pi^{2}}{\mathrm{~L}^{2}} \mathrm{EI} \delta \Leftrightarrow(\mathrm{e}+\delta) \mathrm{F}=\frac{\pi^{2} \mathrm{E}_{0} \mathrm{I}}{\mathrm{L}^{2}}\left(1-\frac{\mathrm{F}}{\mathrm{F}_{\mathrm{u}}}\right) \delta \Leftrightarrow \mathrm{e} \frac{\mathrm{F}}{\mathrm{F}_{\mathrm{E}}}=\left(1-\frac{\mathrm{F}}{\mathrm{F}_{\mathrm{u}}}-\frac{\mathrm{F}}{\mathrm{F}_{\mathrm{E}}}\right) \delta \Leftrightarrow \\
& \mathrm{e} \frac{\mathrm{F}}{\mathrm{F}_{\mathrm{E}}}=\delta\left(1-\frac{\mathrm{F}}{\mathrm{F}_{\mathrm{R}}}\right) \quad \Leftrightarrow \mathrm{e}+\delta=\mathrm{e} \frac{1-\frac{\mathrm{F}}{\mathrm{F}_{\mathrm{R}}}+\frac{\mathrm{F}}{\mathrm{F}_{\mathrm{E}}}}{1-\frac{\mathrm{F}}{\mathrm{F}_{\mathrm{R}}}} \Leftrightarrow \frac{\mathrm{e}+\delta=\mathrm{e} \frac{\mathrm{F}}{\frac{\mathrm{F}_{\mathrm{u}}}{1-\frac{\mathrm{F}}{\mathrm{F}_{\mathrm{R}}}}}}{}
\end{aligned}
$$




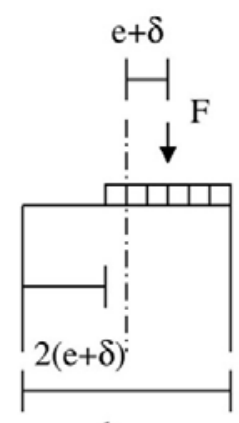

$\mathrm{h}$
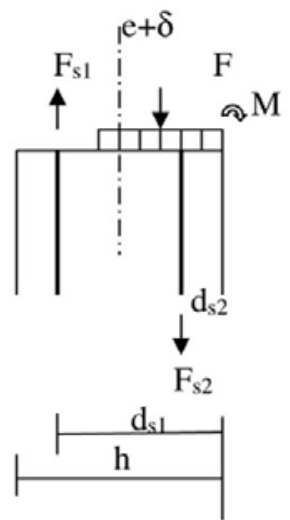

Figure 6. Column cross section in compression and in compression and tension.

Considering a compression stress block representing the ultimate capacity of a cross section of height $\mathrm{h}$ (Figure 6) we get an expression of the load-bearing capacity of a compressed unreinforced- or reinforced column as

$$
\frac{F}{F_{u}}=\frac{h-2(e+\delta)}{h} \Leftrightarrow \frac{F}{F_{u}}=1-2 \frac{e}{h} \frac{1-\frac{F}{F_{u}}}{1-\frac{F}{F_{R}}} \Leftrightarrow 1-\frac{F}{F_{R}}=2 \frac{e}{h} \Leftrightarrow \underline{=\frac{F=F_{R}\left(1-2 \frac{e}{h}\right)}{P}}
$$

For larger eccentricities the deflection of a reinforced cross-section is assessed from the curvature calculated for the ultimate resistance of the cross-section from the ultimate strain $\varepsilon_{c u}$ in concrete and yield strain $\varepsilon_{s y}$ in reinforcement. The yield force of the tension reinforcement is $F_{s 1}$ in the depth $d_{s} 1$ from the compressed edge. The yield force $\mathrm{F}_{\mathrm{s} 2}$ in the compression reinforcement in the depth $\mathrm{d}_{\mathrm{s} 2} \mathrm{can}$ be obtained since the yield strain of the reinforcement remains the same at high temperatures and the ultimate strain for concrete increases.

Still presuming a sinus deflection and defining the ultimate deflection $\delta_{\mathrm{u}}$ and the moment $\mathrm{M}$ as calculated about the compressed edge of a cross-section of width c, we get:

$$
\delta_{\mathrm{u}}=\frac{1}{\pi^{2}} \frac{\varepsilon_{\mathrm{cu}}+\varepsilon_{\mathrm{sy}}}{\mathrm{d}_{\mathrm{s} 1}} \mathrm{~L}^{2} \text { and } \mathrm{M}=-\mathrm{F}\left(\frac{\mathrm{h}}{2}-\mathrm{e}-\delta_{\mathrm{u}}\right) \text { and }
$$

$$
\begin{aligned}
& \underline{\mathrm{F}_{\mathrm{s}}=\mathrm{F}_{\mathrm{s} 1}-\mathrm{F}_{\mathrm{s} 2}} \text { and } \underline{\mathrm{M}_{\mathrm{s}}=\mathrm{d}_{\mathrm{s} 1} \mathrm{~F}_{\mathrm{s} 1}-\mathrm{d}_{\mathrm{s} 2} \mathrm{~F}_{\mathrm{s} 2}} \text { and } \mathrm{M}_{\mathrm{c}}=\left(\mathrm{F}+\mathrm{F}_{\mathrm{s}}\right) \frac{\left(\mathrm{F}+\mathrm{F}_{\mathrm{s}}\right)}{2 \mathrm{cf} \mathrm{fc}_{\mathrm{cc}}} \\
& M=M_{s}-\left(F+F_{s}\right) \frac{\left(F+F_{s}\right)}{2 c f_{c c}} \text { gives } F^{2}+\left(2 F_{s}-\left(\frac{h}{2}-e-\delta_{u}\right) 2 c f_{c c}\right) F+F_{s}^{2}-M_{s} 2 c f_{c c}=0 \\
& \text { If } \mathrm{b}=2 \mathrm{~F}_{\mathrm{s}}-\left(\frac{\mathrm{h}}{2}-\mathrm{e}-\delta_{\mathrm{u}}\right) 2 \mathrm{cf} \text { cc } \quad \text { then } \mathrm{F}=\frac{-\mathrm{b}+\sqrt{\mathrm{b}^{2}-4 \mathrm{~F}_{\mathrm{s}}^{2}+8 \mathrm{cf} \mathrm{fc}_{\mathrm{cc}} \mathrm{M}_{\mathrm{s}}}}{2}
\end{aligned}
$$

This gives an explicit expression of the load-bearing capacity of an eccentrically loaded reinforced concrete column with plastic ultimate limit stress distribution in a deflected condition. 


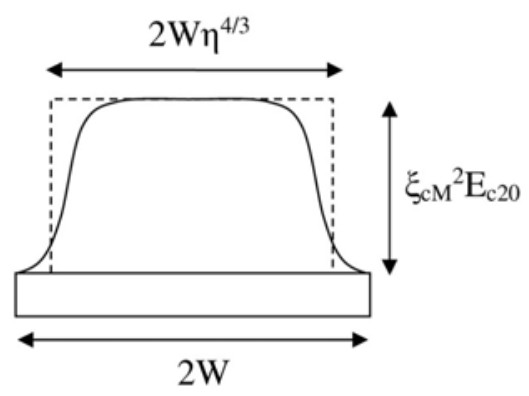

Figure 7. Reduced cross-section for columns.

\section{Column fire calculations}

The author has introduced a reduced cross-section for fire exposed concrete structures in Hertz (1985) and in the Eurocode ENV 1992-1-2 (1995) and later versions. It represents a distribution of the compressive concrete strength through a cross section of the smallest width $2 \mathrm{~W}$ exposed to fire from two sides. The reduced strength in the midpoint is called $\xi_{\mathrm{cm}} f_{\mathrm{cc} 20}$ and the average value through the cross section is called $\eta \xi_{\mathrm{cM}} f_{\mathrm{cc} 20}$. The compressive strength of the cross-section is $2 \mathrm{W \eta} \xi_{\mathrm{cM}} f_{\mathrm{cc} 20}$ that is considered as a stress block of strength $\xi_{\mathrm{cm}} \mathrm{f}_{\mathrm{cc} 20}$ with a width $2 \mathrm{W \eta}$.

You may find the parameters and much more by the free program ConFire Hertz (2012).

For a column the reduced cross-section follows the reduction of the E-modulus, which is $\xi_{\mathrm{cm}}{ }^{2} \mathrm{E}_{\mathrm{c} 20}$ in the midpoint and the width of the stiffness block giving the right reduction of the axial and flexural stiffness of the cross-section is found to be $2 \mathrm{~W}^{4 / 3}$ (Figure 7). This means that the model of a fire exposed column or wall is reduced by $\mathrm{W}\left(1-\eta^{4 / 3}\right)$ from all fire exposed sides, where $\mathrm{W}$ is the smallest thickness to the midpoint of a column or the thickness of a one-sided fire exposed wall.

The expressions derived above all apply for a cross-section of a column reduced like this, where the compressed edge now is the compressed edge of the reduced cross-section.

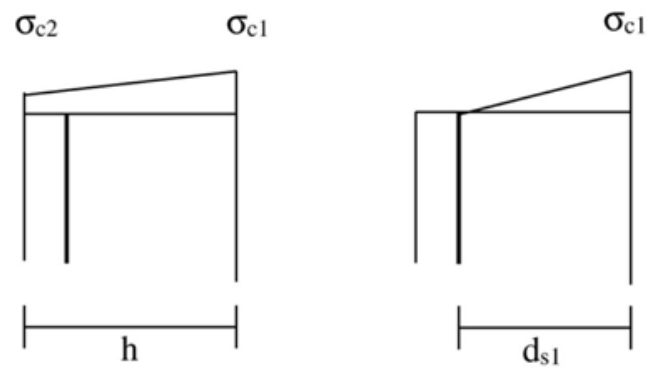

Figure 8. Cross-section in full compression and in compression and tension.

The thermal deflection is important and can be regarded as a part of the eccentricity e. Since we consider the fire exposure uniform along the height as it is in tests, the thermal deflection will have a shape of a circular arch,. Using a constant coefficient of thermal elongation $1.1 * 10^{-5}$ for concrete as well as for steel we get for a cross-section with compression in both sides $\sigma_{\mathrm{c} 1}$ and $\sigma_{\mathrm{c} 2}$ respectively (Figure 8)

$$
\begin{aligned}
& \mathrm{e}_{\mathrm{th}}=\frac{1}{8} \frac{1.1 \cdot 10^{-5}\left(\mathrm{k}_{\mathrm{tr} 2} \mathrm{~T}_{\mathrm{c} 2}-\mathrm{k}_{\mathrm{tr} 1} \mathrm{~T}_{\mathrm{c} 1}\right)}{\mathrm{h}} \mathrm{L}^{2} \text { where } \\
& \mathrm{k}_{\mathrm{tr} 1}=\max \left\{\begin{array}{c}
1-2.35 \frac{\sigma_{\mathrm{c} 1}}{\mathrm{f}_{\mathrm{cc} 20}} \\
0
\end{array}\right\} \text { and } \mathrm{k}_{\mathrm{tr} 2}=\max \left\{\begin{array}{c}
1-2.35 \frac{\sigma_{\mathrm{c} 2}}{\mathrm{f}_{\mathrm{cc} 20}} \\
0
\end{array}\right\}
\end{aligned}
$$

$\mathrm{k}_{\text {tr1 }}$ and $\mathrm{k}_{\mathrm{tr} 2}$ are factors taking the transient strain into account. The reinforcement usually have 10 time larger E-modulus but 100 times smaller cross-section than concrete, and therefore the effect of different transient strain is not taken into account. 


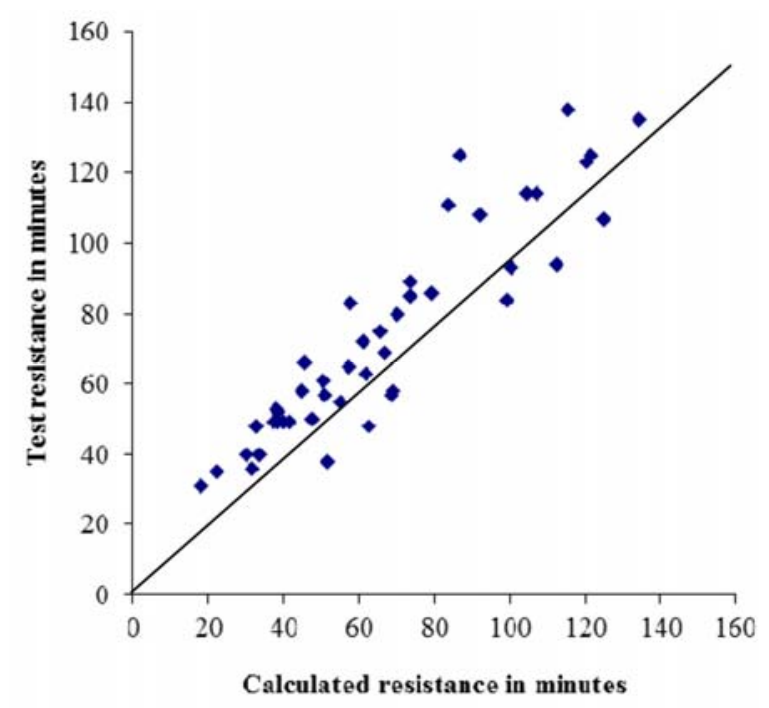

Figure 9. Tested column resistance according to Hass (1986) et al (see below) versus results of the presented calculations.

The values correspond to those proposed by Anderberg and Thelandersson (1976) and approximately in accordance with the first part of the so called "Master curves" by Khoury, Grainger, and Sullivan (1985). Furthermore, they also corresponds with loaded material fire tests made by the author.

Transient strain may be considered as a part of the thermal strain that does not take place if the concrete is loaded in compression during heating. Aggregate expands and cement matrix contracts giving rise to crack formation at $300^{\circ} \mathrm{C}$. These internal thermal cracks are main responsible for the thermal strain, and it is obvious that a compressive load on the material will delay or hinder the crack formation and thereby hinder the thermal elongation.

If the cross-section is subjected to compression and tension, the reinforcement is responsible for the thermal elongation in the tensioned side, and you get

$$
\mathrm{e}_{\mathrm{th}}=\frac{1}{8} \frac{1.1 \cdot 10^{-5}\left(\mathrm{~T}_{\mathrm{s}}-\mathrm{k}_{\mathrm{tr} 1} \mathrm{~T}_{\mathrm{c}}\right)}{\mathrm{d}_{\mathrm{s} 1}} \mathrm{~L}^{2} \quad \text { where } \mathrm{k}_{\mathrm{tr} 1}=\max \left\{\begin{array}{c}
1-2.35 \frac{\sigma_{\mathrm{c} 1}}{\mathrm{f}_{\mathrm{cc} 20}} \\
0
\end{array}\right\}
$$

The thermal eccentricity is added to the statical eccentricity, and the load-bearing capacity of a central or eccentric loaded column or wall can be estimated at any time of a fire or in a cold condition after a fire by the formulas presented above.

50 tests have been recalculated representing variations in column length, cross section dimensions, reinforcement, concrete quality, axial load, and eccentricity of load and of fire exposure.

45 of the tests are reported in Hass 1986 mainly of German siliceous concrete. 2 columns are from Lie et.al.1984 (number 61 and 62). 2 tests are from Seekamp et.al. 1964 (number 71 and 72). 1 tree sided exposed column is from Anderberg and Forsén 1982 (number 81).

As shown on Figure 9 the calculation results for the 50 columns are in general on the safe side compared to test results, and a reasonable agreement is observed. It must therefore be concluded that the calculation method is suitable for design purpose. 

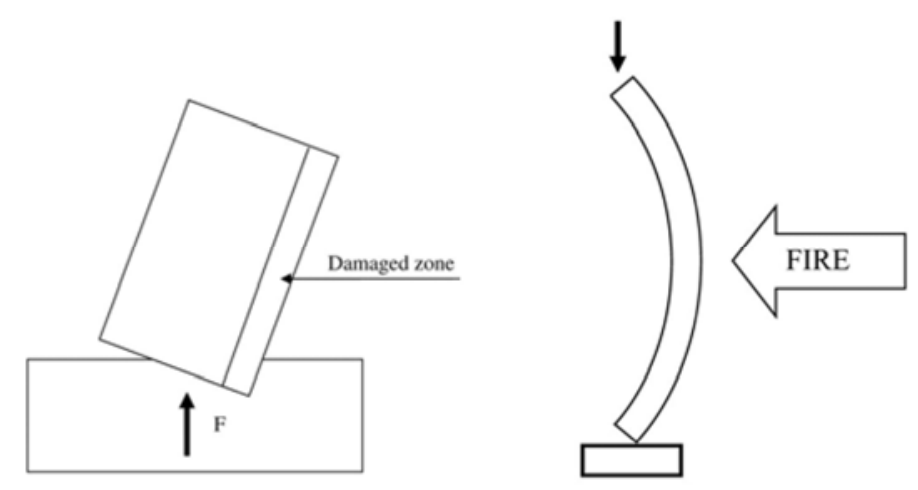

Figure 10. Thermal eccentricity at the bottom of a wall.

For walls with fire exposure on the one side the author finds that a simple one step calculation is not possible. The reason is that the thermal deformation towards the fire is significantly affecting the stresses in the cross section. The changes of the transient strains and stress distribution at intervals during the heating affects the further deformation and thereby the further stress- strain distributions. You therefore have to apply a more elaborate method of estimating the load-bearing capacity and the deformation of an eccentric loaded wall with fire at one side.

In this method the author divides the cross-section into 10 lamellas from the fire exposed surface to the back of a wall. He divides the fire into time steps of 10 minutes, and for each step he calculates the stiffness, stress, strain, and transient strain of each lamella while the column is loaded by a specific load with a specific eccentricity. From that he finds the overall deflection influencing the stressdistribution in the next time step. At each time step he then finds the load-bearing capacity by application of the general column theory presented above establishing equilibrium in a deflected condition between external and internal moments. When the load-bearing capacity meets the applied load, the actual time is the fire duration. Alternatively, if the load-bearing capacity does not exceed the load for a fully developed fire, the wall can withstand its load.

Since these calculations are somewhat laborious we have made a free program ConWall Hertz (2017) doing them in 10 minutes time steps.

Often you apply a support of a wall in a fire test, where the bottom is resting at a plain surface. In these cases the thermal deformation may give rise to an additional eccentricity as shown in Figure 10. The eccentricity is found by calculating the depth of the crushed zone of concrete needed to adopt the applied force. At each time step you then add the average value of the eccentricity at the top and bottom to the transient thermal eccentricity in order to find the resulting eccentricity for the next time step and for the stability check.

In some cases you experience that a wall is first moving inwards towards the fire due to thermal deformation, and then it may move outwards again due to increased eccentricity of the load because of the increased damaged zone and the increased transient strain inside the damaged zone.

In such cases you may experience that the wall brakes in failure outwards so that the direction of deflection will shift. This is modelled by the presented theory, and observed at some of the authors fullscale tests.

Results of full-scale tests are compared with results of this more elaborate calculation in order to document the validity of the design method. 


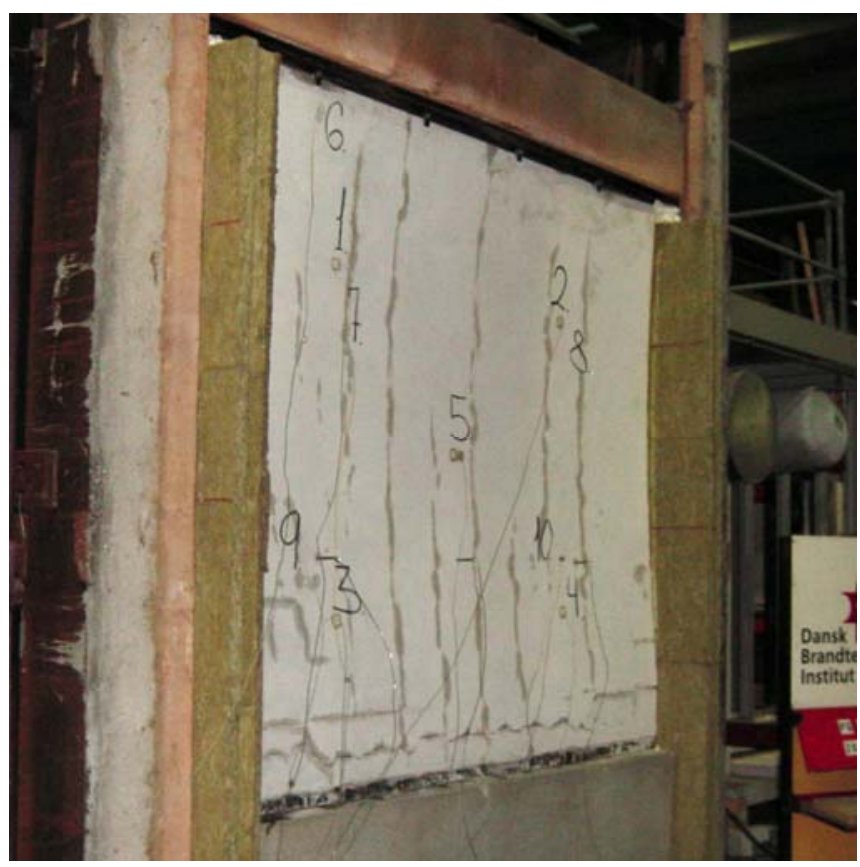

Figure 11. Eccentric loaded $100 \mathrm{~mm}$ block wall of concrete $600 \mathrm{~kg} / \mathrm{m} 3$ in fire test at $124 \mathrm{~min}$

\section{Wall element tests}

The test walls were supported by a flat bearing at the bottom as shown in Figure 10 and by an eccentric placed hinge at the top insulated to the sides by ceramic fiber wool.

In the first phase of the project, we deliberately gave the test walls an initial load eccentricity, which gave compression along the wall surface towards the fire. We call that positive eccentricity.

Since the thermal deformation also tends to give compression towards the fire the eccentricity thereby contributed the most to the transient strain. On the other hand, this eccentricity also gave the most stable conditions because the external load counteracted the thermal deflection.

In the second phase, we therefore decided to use a load with a negative eccentricity giving compression at the wall surface away from the fire, which tend to increase the thermal deflection. This is the worst case that represents the decisive loading for a wall. By using positive as well as negative eccentricities the test results serve as a check for the calculation methods, and in addition they may serve as a direct documentation for application of the specific walls.

In the first phase, we at first calculated the support conditions as a hinge at top and bottom. However, in the tests the walls rested flat at the bottom support (Figure 10). This gives rise to an eccentricity, which we included in the calculation method as described above.

Since this seems to be the most correct model of the support conditions in practice we kept them in the tests of the second phase.

The result was the new calculation method presented above, and it was used calculating all the tests (Figures 1, 11, and 12). This means that we recalculated the tests of phase 1 with the new support conditions, and therefore the calculations presented here are not equal to those, which can be found in our very first report (Hertz and de Place Hansen (2001)).

The test results and the calculated fire resistance times are found in Table 4. 

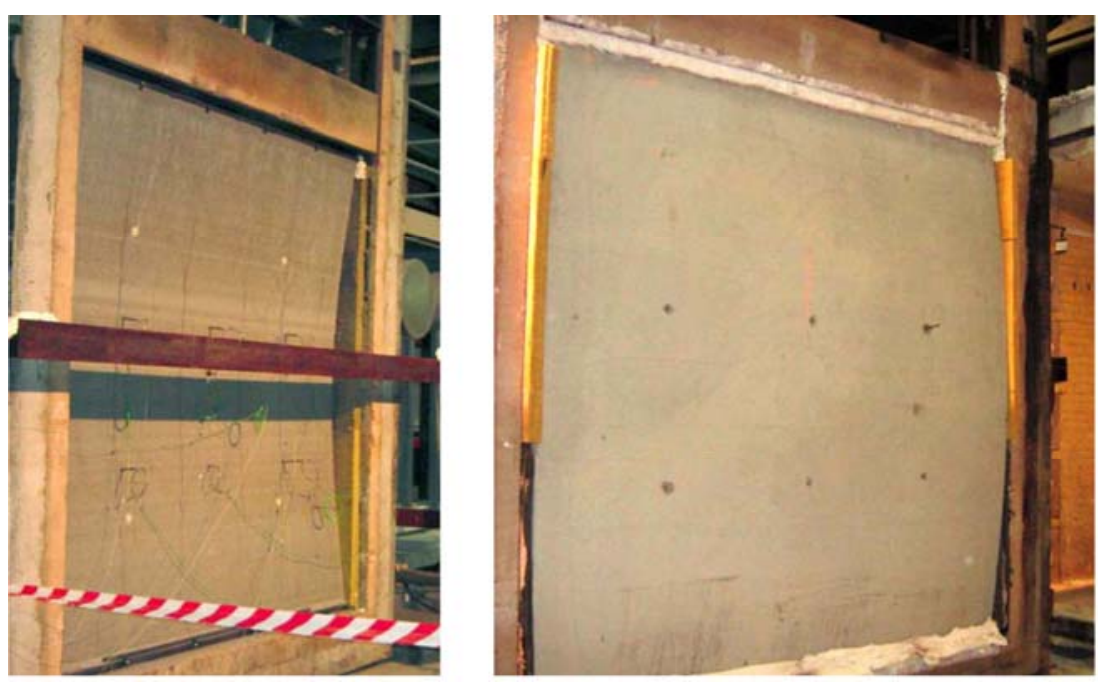

Figure 12. Eccentric loaded $100 \mathrm{~mm}$ wall $1200 \mathrm{~kg} / \mathrm{m}^{3}$ at $95 \mathrm{~min}$ and inside after fire.

\begin{tabular}{|l|r|r|r|r|r|r|r|}
\hline Density $\rho \mathrm{kg} / \mathrm{m}^{3}$ & 1800 & 1800 & 1200 & 1200 & 900 & 600 & 600 \\
\hline Eccentricity e m & -0.020 & 0.020 & -0.020 & 0.020 & -0.010 & -0.015 & 0.020 \\
\hline Load F kN & 40.0 & 70.0 & 25.0 & 35.0 & 108.0 & 7.5 & 10.0 \\
\hline Thickness W m & 0.10 & 0.10 & 0.10 & 0.10 & 0.15 & 0.105 & 0.090 \\
\hline Height L m & 3.00 & 3.00 & 3.00 & 3.00 & 2.50 & 2.40 & 3.00 \\
\hline Compressive strength fcc20 MPa & 20.0 & 20.0 & 10.5 & 10.5 & 3.00 & 3.75 & 3.75 \\
\hline E-modulus Ecc20 GPa & 18.0 & 18.0 & 8.00 & 8.00 & 3.00 & 2.50 & 2.50 \\
\hline Tensile strength fct20 MPa & 3.20 & 3.20 & 2.20 & 2.20 & 1.00 & 0.30 & 0.30 \\
\hline Conductivity $\lambda \mathrm{WC}$ & 0.90 & 0.90 & 0.45 & 0.45 & 0.40 & 0.30 & 0.30 \\
\hline Picture in Figure & 1 & - & 12 & - & - & 11 & - \\
\hline Deflection at end of test $\delta \mathrm{mm}$ & 168 & 137 & 173 & 130 & -5 & 70 & - \\
\hline Test result ttest min & 85 & 78 & 96 & 154 & 198 & 120 & 36 \\
\hline Calculated t min & 75 & 58 & 83 & 75 & 153 & 107 & 32 \\
\hline
\end{tabular}

Table 4. Data for test of fire exposed eccentric loaded light-aggregate walls.

\section{Conclusion}

The derived formulas for column stability and the simplified model of a reduced cross-section gives reasonable results slightly on the safe side for eccentrically loaded concrete columns exposed to fire.

For walls exposed to fire at only one side the transient thermal deflection depends significantly more on changes in stress-distribution during the fire exposure calling for a calculation in time steps.

Such time step calculations show reasonable results slightly on the safe side for the full-scale tested eccentrically loaded light aggregate concrete walls exposed to fire on the one side with densities ranging from $1800 \mathrm{~kg} / \mathrm{m}^{3}$ to $600 \mathrm{~kg} / \mathrm{m}^{3}$.

The first test made with density $1200 \mathrm{~kg} / \mathrm{m}^{3}$ and positive eccentricity $0.02 \mathrm{~m}$ did brake after a larger time than calculated probably due to inaccuracy in placing the top hinge. This is more difficult for positive- than for negative eccentricity because positive eccentricity gives equilibrium with the thermal deflection and therefore small deviations may give long fire resistance times. 


\section{References}

Achenbach, M. Morgenthal, G. (2016) "Extension of the Zone Method of Eurocode 2 for reinforced concrete columns subjected to standard fire”. Journal of Structural Fire Engineering, Vol. 7 No. 2, pp. 82-96.

Anderberg, Y. Thelandersson, S. (1976) "Stress and deformation characteristics of concrete at high temperatures. 2. Experimental Investigation and Material Behaviour Model." Bulletin 54, Lund Institute of Technology. Lund.

Anderberg, Y. Forsén, N. 1982 "Fire Resistance of Concrete Structures."

Nordic Concrete Research No.1. Oslo 1982.

Andersen, N. (2000) "Prøvningsrapport, Flisevceg" (Test report tile wall) Danish Institute of Fire Technology Case No. PG10642 A

Andersen, N. (2000) "Prøvningsrapport, Blokvceg" (Test report Block wall) Danish Institute of Fire Technology Case No. PG10642 B.

Andersen, N. (2001) "Prøvningsrapport, Helvceg 1200 kg/m3" (Test report Full wall 1200 kg/m3) Danish Institute of Fire Technology Case No. PG10642 D.

Andersen, N. (2001) "Prøvningsrapport, Helvœe 1800 kg/m3" (Test report Full wall 1800 kg/m3) Danish Institute of Fire Technology Case No. PG10642 C.

Andersen, N. (2001) "Prøvningsrapport, Massiv dcek sandwichdcek" (Test report Massive deck, sandwich deck ) Danish Institute of Fire Technology Case No. PG10742 E.

Andersen, N. (2002) "Prøvningsrapport, Blokvceg 600 kg/m3" (Test report block wall 600 kg/m3) Danish Institute of Fire Technology Case No. PG10927.

Andersen, N. (2002) "Prøvningsrapport, Blokvceg 1200 kg/m3" (Test report block wall 1200 kg/m3) Danish Institute of Fire Technology Case No. PG10929.

Andersen, N. (2002) "Prøvningsrapport, Blokvceg 1800 kg/m3" (Test report block wall 1800 kg/m3) Danish Institute of Fire Technology Case No. PG10928.

Andersen, N. (2002) "Prøvningsrapport, Deek 1 Sandwich deck" (Test report deck 1 Sandwich deck) Danish Institute of Fire Technology Case No. PG10930.

Andersen, N. (2002) "Prøvningsrapport, Deek 2 Massivt dcek" (Test report deck 2 Massive deck) Danish Institute of Fire Technology Case No. PG10931.

Danish Standards: (1999) DS411 "Norm for betonkonstruktioner" (Code of practice for the structural use of concrete). $111 \mathrm{p}$.

ENV 1992-1-2. (1995) Design of concrete structures, General rules - Structural fire design. 85p.

EN 1992-1-2 (2004) Design of concrete structures - Part 1-2: General rules -Structural fire design. 97p.

Fischer, R. (1970) "Über das Verhalten von Zementmörtel und Beton bei höheren Temperaturen."

Deutcher Ausschuss für Stahlbeton. Heft 214, pp.61-128. Berlin 1970.

Harada, T. Takeda, J. Yamane, S. Furumura, F. (1972) "Strength, Elasticity and Thermal Properties of Concrete Subjected to Elevated Temperatures."

ACI American Concrete Institute, Special Publication SP-34, pp.377-406. Detroit 1972.

Harmathy, T.Z. Berndt, J.E. (1966) "Hydrated Portland Cement and Light weight Concrete at Elevated Temperatures." Journal of the ACI Vol.63, No.1, pp.93-112. Research Paper No. 280. Division of Building Research. Ottawa 1966.

Hass, R. (1986) “Zur Praxisgerechten Brandschutztechnischen Beurteilung von Stützen aus Stahl und Beton. “ Heft 69. Institut für Baustoffe, Massivbau und Brandschutz der Technishen Universität Braunschweig. Braunschweig.

Hertz. K. D. (1980) "Fire Properties of Concrete Constructions” (In Danish: "Betonkonstruktioners brandtekniske egenskaber") Part 1 of Ph.D.-Thesis.

Reprort No.140. Institute of Building Design, Now: Department of Civil Engineering, Technical University of Denmark. Lyngby 1980. 210p.

Hertz, K. D. (1982) "The Anchorage Capacity of Reinforcing Bars at Normal and High Temperatures". Magazine of Concrete Research Vol.34, No.121, pp.213-220.

Hertz, K.D. (1985) "Analyses of Prestressed Concrete Structures Exposed to Fire”. Report No.174.

Presented at the CIB W14 conference in Kyoto. June 1988CIB W14/85/9 (DK). Institute of Building Design, Technical University of Denmark. Lyngby, 154p.

Hertz, K.D. (1993) “Letter to CEN-TC250 April 1993” Institute of Building Design, and Eurocode Project team CEN/TC250/SC2/PT10. 1993-04-29. 
Hertz, K.D. (1997) "Beregningsmetode til brandteknisk dimensionering af konstruktioner i letklinkerbeton". (Calculation method for fire safety design of constructions of expanded clay aggregate concrete). Dept of Buildings and Energy, TU Denmark. 13 p.

Hertz, K.D. (1998) "Comments on simplified calculation method for fire exposed concrete columns". Report R-017. Dept of Buildings and Energy, TU Denmark. 9 p

Hertz, K.D. de Place Hansen, E. (2001) "Brandteknisk dimensionering af letklinkerbeton - Beregning af brandmodstandstid". (Fire safety design of expanded clay aggregate concrete - Calculation of fire resistance time). DTU Byg. SR-01-10. 43p.

Hertz, K.D. (2002) "Documentation for Calculations of Standard Fire Resistance of Slabs and Walls of Concrete with Expanded Clay Aggregate". Report R-048, DTU Byg. 43p.

Hertz, K. D. (2004) "Reinforcement Data for Fire Safety Design”. Magazine of Concrete Research Vol.56, No.8, pp.453-459.

Hertz, K. D. (2004) "Review of Differences of Steel Related Properties Between Proposals of European Structural Codes”. Report R-099, DTU Byg. 5p.

Hertz, K. D. (2005) “Concrete Strength for Fire Safety Design”. Magazine of Concrete Research Vol.57, No.8, pp.445-453.

Hertz, K. D. (2006) "Quenched reinforcement exposed to fire". Magazine of Concrete Research Vol.58, No.1, pp.43-48.

Hertz, K. D. (2006) “Users guide for the program LKvaegW.” "Vejledning til programmet LKvaegW." Technical University of Denmark. (In Danish). 5p.

Hertz, K. D. (2012) “Users guide for the program Confire." 2. Edition.

Technical University of Denmark. 23p. http://www.byg.dtu.dk/publikationer/software

Hertz, K. D. (2017) "Users guide for the program ConWall."

Technical University of Denmark. 5p. http://www.byg.dtu.dk/publikationer/software

Khoury, G.A. Grainger, B.N. Sullivan, P.J.E. (1985) "Strain of Concrete during First Heating to $600^{\circ} \mathrm{C}$ under Load." Magazine of Concrete Research, Vol.37, No.133, pp.195-215. CIB W14/86/45 (UK)

Lie, T.T. Allen, D.E. Abrams, M.S. (1984) “Fire Resistance of Reinforced Concrete Columns.” DBR Paper No. 1167. National Research Council Canada. Ottawa 1984.

Schneider, U. (1977) "Festigkeits- und Verformungsverhalten von Beton unter stationär und instationärer Temperaturbeanspruchung." Die Bautechnik heft 4. pp.123-132. Wilhelm Ernst und Sohn. Berlin 1977.

Seekamp, H. Becker, W. Struck, W. (1964) "Brandversuche an Stahlbetonfertigsäulen.” Deutscher Ausschuss für Stahlbeton. Heft 162, Teil 1. Wilhelm Ernst und Sohn. Berlin 1964.

\section{Corresponding author}

Kristian Hertz can be contacted at khz@byg.dtu.dk 